party will go to New Zealand, where animal and plant life and geological formations are of peculiar interest. The official secretary of New Zealand has written to say that everything possible will be done to make their stay in that country a success. It is expected that the return voyage will end in Vancouver about September 9 in time for the opening of the university.

\section{THE SECTION OF MEDICAL SCIENCES OF THE AMERICAN ASSOCIATION}

IT may be of some interest, in this period of co-ordination, to know that at the Toronto meeting a group of parasitologists, medical entomologists and medical workers met and decided upon the following policy for Section N, Medical Sciences:

1. That it was extremely desirable and necessary that a closer co-ordination between parasitologists, entomologists and medical workers be worked out.

2. That the secretary of Section N (Medical Science), after consulation with the secretaries of the related societies, arrange for a program which will avoid conflicts with related groups.

3. That the secretaries of the allied societies, co-operating with the secretary of Section $\mathrm{N}$ (Medical Sciences), suggest those of its members who might be invited to take part in a symposium at which the significant researche; are reported that are of interest to the allied groups of workers.

4. It was deemed undesirable to attempt for: the present any formal co-operation between these related societies.

5. That the time has come when there is a definite need for the discussion of such papers as affect the interests in the allied groups, both for stimulation and for information.

6. That each secretary so arrange the paper's of its society's program that it may be possible for its members to meet with Section N (Medical Sciences) without too serious a loss.

7. That the joint meeting be held under the auspices of Section N (Medical Sciences).

Section N (Medical Sciences) is proceeding with this policy on the assumption that such arrangements will in no way conflict with any program that may be adopted at the Washington conference, held under the auspices of the National Research Council.

A. J. GoldFarb, Secretary.

\section{THE BOCHER MEMORIAL PRIZE OF THE} AMERICAN MATHEMATICAL SOCIETY

THE American Mathematical Society announces the foundation of a prize in memory of the late Professor Maxime Bôcher, of Harvard University. Soon after the death of Professor Bôcher, in 1918, a fund was raised in his memory through the efforts of Professor T. S. Fiske, of Columbia University, which was turned over to the American Mathematical Society. On recommendation of a committee of which Professor E. B. Van Vleck, of the University of Wisconsin, was chairman, the council of the society has decided to devote the interest of this: fund to the establishment of a prize, to be called the Bôcher Memorial Prize, and to be awarded at five year intervals, for a notable researeh memoir published in the Transactions of the American Mathematical Society during the preceding five years by a resident of the United States or Canada. The age of the recipient shall not be over forty years, and the prize shall not be awarded twice to the same person. The first award (of \$100) is to be made for it memoir published during the period 1918-1922, and will be conferred at some meeting of the society in 1923 .

This prize, which is believed to be the first mathematical prize to be given in this country at regular intervals for research in pure mathematics, is an especially appropriate memorial for Professor Bôcher, not only because of his achievements in research, but also because of his great services to mathematies in this country as one of the founders and for many years one of the editors of the Transactions of the American Mathematical Society; for this latter reason the provision that the prize must be awarded for a memoir published in the Transactions: seems particularly appropriate. 